\title{
APPLICATION OF GLUTARALDEHYDE-CROSSLIN KED CHITOSAN MEMBRANES FROM SHRIMP SHELLWASTE ON PRODUCTION OF BIODIESEL FROM CALOPHYLLUM INOPHYLLUM OIL
}

\author{
Siti Wafiroh ${ }^{1, *}$, Murobbiyatul Wathoniyyah ${ }^{1}$, Abdulloh Abdulloh $^{1}$, Yanuardi Rahardjo ${ }^{1}$, \\ Mochamad Zakki Fahmi ${ }^{1}$
}

DOI: dx.doi.org/10.23939/chcht11.01.065

\begin{abstract}
The purification of biodiesel was performed using glutaraldehyde-crosslinked chitosan membrane to improve the quality and to reduce the cost of biodiesel production. Biodiesel was obtained by acid-based catalyzed transesterification of Calophyllum inophyllum oil. The results of this experiment showed that the amount of glycerol in biodiesel before the process is $0.3014 \pm 0.05 \%$. After the purification process performed for $1 \mathrm{~h}$, the glycerol content in biodiesel has been reduced to $0.1429 \pm 0.09 \%$.
\end{abstract}

Keywords: biodiesel, glycerol, crosslink, chitosan, membrane.

\section{Introduction}

Since last two decades the prediction on increasing demand of petroleum has been established, it was coupled with limitation on accessible oil [1]. The availability of oil feed stocks is a main reason in a push to more sustainable alternatives. Among sustainable supplies, renewable resources that perform short cycle, were fully considered. Covering these problems, biodiesel promises to be an alternative for fossil fuels as a source of carbon for the chemical and material needs. Biodiesel is an attractive substitute for petro-diesel fuel because it is environmentally beneficial, thus has a biodegradable and low gas emission profile [2]. Biodiesel usually in the form of fatty acid methyl esters (FAME) is often derived from either the transesterification of triglycerides or the esterification of free fatty acids (FFA) with methanol. As a substitute to diesel fuel, biodiesel is commonly produced

\footnotetext{
${ }^{1}$ Airlangga University, Faculty of Science and Technology, Department of Chemistry, Surabaya 60115, Indonesia m.zakki.fahmi@fst.unair.ac.id

(C) Wafiroh S., Wathoniyyah M., Abdulloh A., Rahardjo Y., Fahmi MZ., 2017
}

from renewable natural sources such as vegetable oils, animal fats and microalga oil. Biodiesel is considered to be carbon neutral because biodiesel yielding plants such as Jatrophacurcas, rape plant and palm trees absorb carbon-dioxide to a greater extent than that used as a fuel in diesel engines.

During biodiesel synthesis, glycerol is the main byproduct which has different phases from biodiesel. So far, glycerol is widely used for pharmaceutics, cosmetics, foods, polymers, surfactants and lubricants [3]. However, the presence of glycerol in biodiesel is undesirable because it is responsible for fuel tank damage, decreasing engine performance [4] and acrolein releasing into the atmosphere [5], which takes place when fuel burning occurs at the temperatures above $453 \mathrm{~K}$. Therefore, the amount of glycerol in the fuel should be reduced to a minimum and it makes biodiesel development as a major issue regarding strategies on its developing on commercial scale [6]. Membrane technology has been applied in various industrial processes such as petrochemical, vegetable oil processing, food and beverage industries, desalination of sea water, pharmaceutics, sterilization of bacteria, industrial wastewater treatment, purification of VCO, sugar cane extract refining, etc. [7]. Introducing membrane for biodiesel purification was proposed by Dube et al. [8] who built a membrane carbon reactor in a biodiesel reactor. The membrane successfully separated unreacted oils, thus generating a high purity biodiesel and shifting the equilibrium towards products. Wang et al. [9] further used ceramic membrane for biodiesel purification, where membrane good properties were shown, including solvent resistance, high temperature resistance, high mechanical strength and easy making. However, ceramic has disadvantages like brittleness, expensive production cost due to energy consumption and needing of high temperature for its production [2]. Therefore, improvement of research in developing other membranes from 
suitable materials, like natural polymers, was a critical issue to overcome limitations of membrane application relating to creation of high quality membrane for biodiesel production with mechanical properties and high thermal stability at low production cost. However, the distinctive features performed by the natural polymer, such as biodegradability, sustainability, super-hydrophobicity and high surface area, became the main consideration on application natural polymer at water-oil separation [10].

Among several natural polymers explored, chitosan was a common choice for many applications in medicine [11], food [12] and industry processing [13]. This material that can be created from skin of crustaceans performs excellent properties relating to biocompatibility, nontoxicity, and biodegradability [14]. However, application of crosslinked chitosan as a membrane for biodiesel purification was not deeply explored so far.

The present work was aimed to find alternative methods for biodiesel purification using the membrane to increase biodiesel production efficiency and reduce environmental pollution. Utilized biodiesel was produced from transesterification of Calophyllum inophyllum (CI) oil. Moreover, the obtained chitosan membrane was further crosslinked with glutaraldehyde to improve its mechanical properties. Several tests and measurements were carried out to determine the membrane mechanical properties and its performance (flux and rejection).

\section{Experimental}

\section{1. $M$ aterials}

In this research we used pro analysis grade chemicals, including $\mathrm{HCl}, \mathrm{NaOH}$, acetic acid, methyl heptadecanoate, phenolphthalein indicator, acetone, $\mathrm{Na}_{2} \mathrm{CO}_{3}$ (purchased from Sigma Aldrich, USA), $n$-hexane, $\mathrm{Na}_{2} \mathrm{SO}_{4}$ anhydrous, $\mathrm{NaIO}_{4}$ and bromotymol blue. $\mathrm{H}_{2} \mathrm{SO}_{4}$, ethanol, $\mathrm{KOH}$, glutaraldehyde, methanol were purchased from Merck, Germany. Shrimp shell was got from seafood market at Surabaya. CI oil was obtained by grinding of CI seed from Surabaya.

\subsection{Experimental Procedure}

\subsubsection{Preparation of chitosan}

Chitosan was created after several processes, namely deproteinization, demineralization, depigmentation and deacetylation. For the first step we removed the protein found in the shell of the shrimp (deproteinization) by adding $3.5 \% \mathrm{NaOH}$ solution to the leather dust shrimp with the ratio between the shrimp shell and $\mathrm{NaOH}$ equal to $1: 10(\mathrm{mg} / \mathrm{ml})$. Then we removed mineral from the shrimp shell (demineralization) by adding $2 \mathrm{~N} \mathrm{HCl}$ to the crude chitin obtained from the deproteinization process with crude chitin: $\mathrm{HCl}$ ratio of $1: 15 \quad(\mathrm{mg} / \mathrm{ml})$. Depigmentation process was done by soaking the chitin in the acetone solvent for $30 \mathrm{~min}$. Lastly we performed deacetylation to transform chitin into chitosan by adding $50 \% \mathrm{NaOH}$ solution into the chitin with chitin: $\mathrm{NaOH}$ ratio being $1: 10(\mathrm{mg} / \mathrm{ml})$. The mixture was boiled at $368 \mathrm{~K}$ for $2 \mathrm{~h}$.

\subsubsection{Preparation of glutaraldehyde-crosslinked chitosan}

For preparing the crosslinked membrane we first made dope by dissolving chitosan in $2 \%$ acetic acid. We also varied weight ratio of glutaraldehyde to chitosan (2.5, $2.7,2.9,3.1$ and $3.3 \%)$. The dope was created by placing $100 \mathrm{mg}$ of chitosan and $2.5 \mathrm{ml}$ of $2 \%$ acetic acid in a closed Erlenmeyer flask and stirring at room temperature using a magnetic stirrer until chitosan was completely dissolved and degassed overnight to eliminate air bubbles. The solution was further proceeded to form the membrane by the phase inversion method. After being washed with DI-water and dried, the membrane was soaked with glutaraldehyde for $1 \mathrm{~h}$. The glutaraldehyde concentration was also varied within $0.01-0.05 \%$. The prepared membrane was characterized by determining the flux, rejection, morphology and mechanical properties with SEM. The flux (permeability) was calculated according to Eq. (1):

$$
J=\frac{V}{A \cdot t}
$$

where $J$ - flux value, $1 \cdot \mathrm{m}^{-2} \mathrm{day}^{-1} ; t-$ time, days; $V$ - volume of permeate, $1 ; A$ - surface area of the membrane, $\mathrm{m}^{2}$.

Rejection was determined by measuring biodiesel turbidity before and after passing the membrane, then we calculated the rejection by Eq. (2):

$$
R=\left(1-\frac{C_{p}}{C_{f}}\right) \cdot 100 \%
$$

where $R$ is the rejection coefficient; $C_{p}$ is the concentration of a substance dissolved in permeate; $C_{f}$ is the concentration of dissolved substances in feeds.

\subsubsection{Characterization of $\mathrm{Cl}$ oil}

Before CI oil being proceeded to become biodiesel, we need to measure its FFA levels, water and fatty acid content and molecular weight. We measured acid value by dissolving $10 \mathrm{~g}$ of $\mathrm{CI}$ in a mixture of $95 \%$ ethanol and diethyl ether with ratio the $1: 1(\mathrm{v} / \mathrm{v})$. Then we titrated the mixture with $0.1 \mathrm{~N} \mathrm{KOH}$. The acid value was determined by Eq. (3): 


$$
\text { Acid value }=\frac{V \cdot N \cdot 56.1}{m}
$$

where $m$ - the weight of CI; $V$ and $N$ - the volume and normality of $\mathrm{KOH}$, respectively [15].

We measured water content of CI oil by heating $\pm 2.5 \mathrm{~g}$ of oil at $373 \mathrm{~K}$ for $1 \mathrm{~h}$ and placed it into a desiccator for $5 \mathrm{~min}$ before it was weighed. The water content in oil is equal to water that evaporates (Indonesian National Standard SNI 01-5009.12-2001) and is measured using below equation:

$$
\text { Water content }=\frac{W_{1}-W_{2}}{W_{1}-W} \cdot 100 \%
$$

where $W$ - the weight of the empty cup; $W_{1}$ - the weight of the cup and oil before heating; $W_{2}-$ the weight of the cup and oil after heating.

Molecular weight and fatty acid content were observed by GC-MS analysis.

\subsubsection{Synthesis of biodiesel}

For the synthesis of biodiesel from CI oil we used acid-based catalyzed transesterification following Berchmans and Hirata's report with some modification [16]. Briefly, CI oil was firstly treated by acid esterification to remove FFA from CI oil, where $0.3 \mathrm{~mol}$ of methanol was mixed with $\mathrm{H}_{2} \mathrm{SO}_{4}(1 \%$ from weight of $\mathrm{CI}$ oil) and stirred after addition of $0.01 \mathrm{~mol}$ of $\mathrm{CI}$ oil at $333 \mathrm{~K}$ for $3 \mathrm{~h}$. The resulted organic phase was further separated by centrifugation. The next process is transesterification reaction. It is the addition of resulted oil into the mix of methanol $(0.3 \mathrm{~mol})$ and $\mathrm{NaOH}$ with $\mathrm{NaOH}$ :oil ratio of 2.5 [16]. The process was maintained at $333 \mathrm{~K}$ for $3 \mathrm{~h}$. The oil phase was then collected for purification process.

\subsubsection{Purification process}

Biodiesel obtained was further purified using glutaraldehyde-crosslinked chitosan membrane. Conversion rate of biodiesel can be determined by Eq. (5):

$$
\text { Biodiesel conversion }=\frac{\sum A-A_{s}}{A_{s}} \cdot \frac{C_{s} V_{s}}{m} \cdot 100 \%
$$

where $\Sigma A$ - total methyl ester peak areas; $A_{s}$ - peak area of the internal standard solution (methyl heptadecanoate); $C_{s}$ - concentration of STD solution $(10 \mathrm{mg} / \mathrm{ml}) ; V_{s}-$ volume of STD solution (5 ml); $m$ - amount of samples (250 $\mathrm{mg}$ ). The amount of glycerol in biodiesel is determined according Indonesian National Standard (SNI 06-1564-1989).

$$
\text { Glycerol }(100 \%)=\frac{\left(T_{1}-T_{2}\right) \cdot N \cdot 9.209}{W}
$$

where $T_{1}-\mathrm{NaOH}$ volume; $T_{2}, N-\mathrm{NaOH}$ volume in titrated sample and blank test, respectively; $W$ - weight of $\mathrm{NaOH}$. Characterization of biodiesel quality was performed according to the standard ASTM D6751 and RSNI EB 020551, which include the determination of the levels of alkyl ester and glycerol, viscosity, flash point and cloud point.

\subsubsection{Other characterizations}

For characterization we used several instruments, including GC-MS, UV-Vis spectrophotometer, $\mathrm{pH}$ meter Scott, Differential Scanning Calorimetry (DSC), Autograph, Scanning Electron Microscopy (SEM), Fourier Transform Infrared (FTIR), Oswald Viscometer.

\section{Results and Discussion}

Chitosan was prepared by isolating chitin from the shrimp shell. Deproteinization process produces crude chitin or rough chitin and changes the shrimp shell color from reddish-brown to brownish-yellow; this is due to the termination of the chemical bond between chitin and proteins so that the pigment of the shrimp shell is dissolved. Crude chitin yield was $48.08 \%$. Demineralization is a process to remove inorganic compounds or minerals in the form of $\mathrm{CaCO}_{3}$ and $\mathrm{Ca}_{3}\left(\mathrm{PO}_{4}\right)_{2}$ from the shrimp shells [17]. Minerals were removed by soaking crude chitin in $2 \mathrm{~N} \mathrm{HCl}$ solution, with the shrimp shell: $\mathrm{HCl}$ ratio being $1: 15(\mathrm{mg} / \mathrm{ml})$, for $30 \mathrm{~min}$ at room temperature. The reaction that occurs during demineralization process is as follows:

$$
\begin{gathered}
\mathrm{CaCO}_{3(\mathrm{~s})}+2 \mathrm{HCl}_{(\mathrm{aq})} \rightarrow \mathrm{CaCl}_{2(\mathrm{aq})}+\mathrm{H}_{2} \mathrm{O}_{(\mathrm{l})}+\mathrm{CO}_{2(\mathrm{~g})} \\
\mathrm{Ca}_{3}\left(\mathrm{PO}_{4}\right)_{2(\mathrm{~s})}+4 \mathrm{HCl}_{(\mathrm{aq})} \rightarrow 2 \mathrm{CaCl}_{2(\mathrm{aq})}+\mathrm{Ca}\left(\mathrm{H}_{2} \mathrm{PO}_{4}\right)_{2(\mathrm{aq})}
\end{gathered}
$$

The crude chitin gained from demineralization was $15.59 \%$. In the next process crude chitin was performed by soaking crude chitin in acetone solvents for $30 \mathrm{~min}$ for depigmentation. The obtained chitin yield was $14.22 \%$. The transformation of chitin to chitosan (deacetylation) was done by breaking the acetyl group bonds of chitin with nitrogen, so that it turned into an amine group $\left(\mathrm{NH}_{2}\right)$. This reaction produces white chitin with the yield of $24.2 \%$. Several characterizations, including a solubility test and a functional group analysis were conducted to determine the quality of chitin and chitosan obtained from isolation procedure. The solubility tests were done to determine the formation of chitosan. If the sample is soluble in $2 \%$ acetic acid, the sample was chitosan, if insoluble - chitin. We further investigated the functional groups and determined the degree of deacetylation of chitin and chitosan using FTIR (Fig. 1). In general, FTIR spectrum of chitosan in this study was quite similar with that of commercial chitosan and chitin performed in reported studies, where common vibrations at 3448 (i), 
2931 (ii), and $1658 \mathrm{~cm}^{-1}$ (iii) corresponding to O-H, C-H, and $\mathrm{C}=\mathrm{C}$ in the main chain, respectively, as well as at $1627 \mathrm{~cm}^{-1}$ (iv) for $\mathrm{N}-\mathrm{H}$ vibration were observed [18]. Furthermore, the transformation of chitosan from chitin is confirmed by decreasing transmittance of $\mathrm{C}-\mathrm{N}$ stretching of chitosan's amide group at $1319 \mathrm{~cm}^{-1}(v)$. Following the method described in the previous report [17], deacetylation degrees (\%DD) of chitin and chitosan obtained in this research were 66.67 and $75.71 \%$, respectively. The average molar weight of chitosan determined by viscometric method was $552.6 \mathrm{~kg} / \mathrm{mol}$. Based on the literature, this value is in accordance with molar weight of normal chitosan, which average molar weight is within 190-700 kg/mol [19].

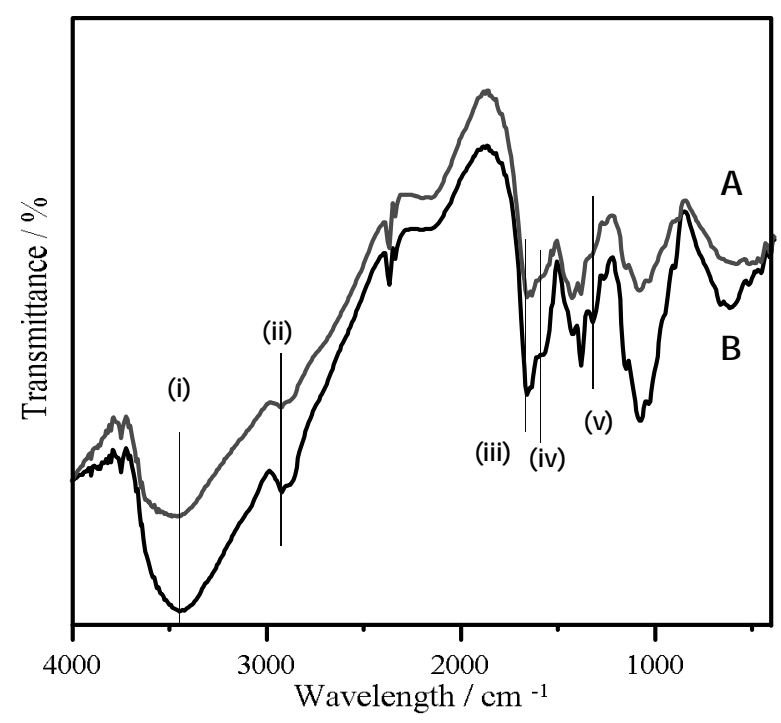

Fig. 1. FTIR spectra of prepared chitin (A) and chitosan (B)

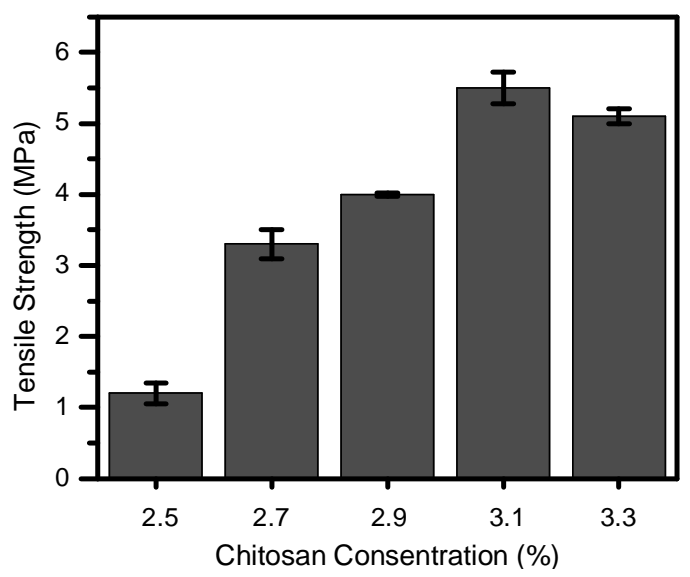

Fig. 2. Mechanical properties of chitosan varied membrane
Glutaraldehyde-crosslinked chitosan membrane was produced using the phase inversion method by evaporating the solvent after printing the membrane on the glass plate. A phase inversion method is based on the principle of thermodynamics, where the initial solution is stable. The inversion process emerges from instability conditions that change process from liquid to solid [20]. By varying chitosan concentration, the mechanical properties of the membranes were investigated (Fig. 2). Fig. 2 shows the correlation between chitosan concentration and its mechanical properties (tensile strength), where the tensile strength value of the membrane increases with the increase in chitosan concentration. Enhancement of chitosan content increases a number of physical attractions between molecules constructing membrane, such as hydrogen and van der Waals bonding. This condition is a responsible reason for this increasing stress value. However, the stress decreases when chitosan concentration is $3.3 \%$. The nature of chitosan, which is water-insoluble, interferes the membrane manufacturing and decreases the stress value. The highest stress value of the membrane $(5.45 \mathrm{MPa})$ was reached at chitosan concentration of $3.1 \%$. Therefore, in the further process of manufacturing glutaraldehyde-crosslinked chitosan we used $3.1 \%$ chitosan concentration. The crosslinking process was carried out with following glutaraldehyde concentrations: $0.01,0.02,0.03,0.04$ and $0.05 \%$. Tensile test of the membrane with the varied glutaraldehyde concentrations shows the effect of glutaraldehyde concentrations on the membrane mechanical properties (Fig. 3). The highest membrane stress is $6.6 \mathrm{MPa}$ when glutaraldehyde concentration is about $0.05 \%$. Moreover, the greater the concentration of glutaraldehyde, the higher value of the stress. Crosslink bonding performed by glutaraldehyde and chitosan will improve the membrane mechanical properties.

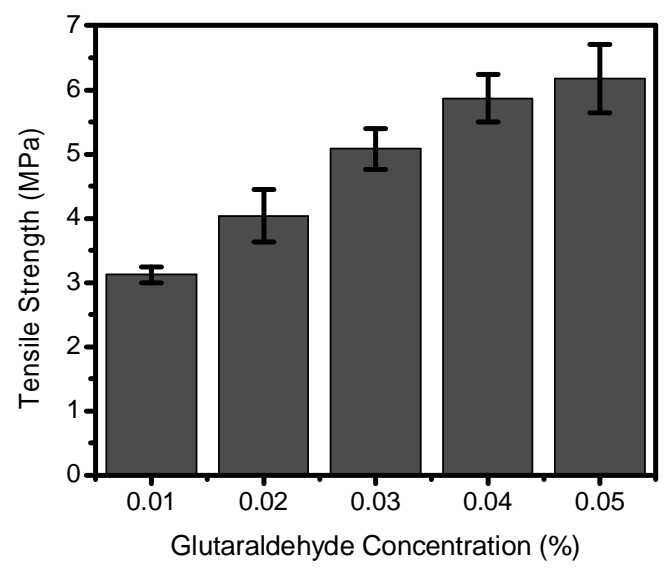

Fig. 3. Mechanical properties of glutaraldehyde varied membrane 

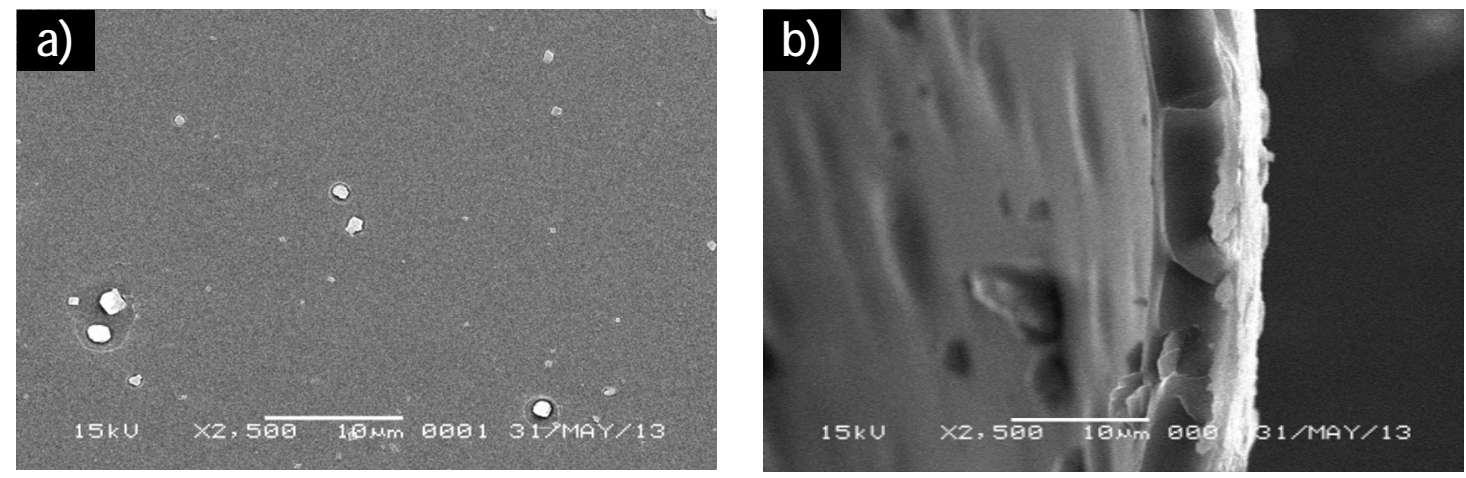

Fig. 4. SEM images of chitosan membrane before crosslinking: surface (a) and the transverse cross-section (b)
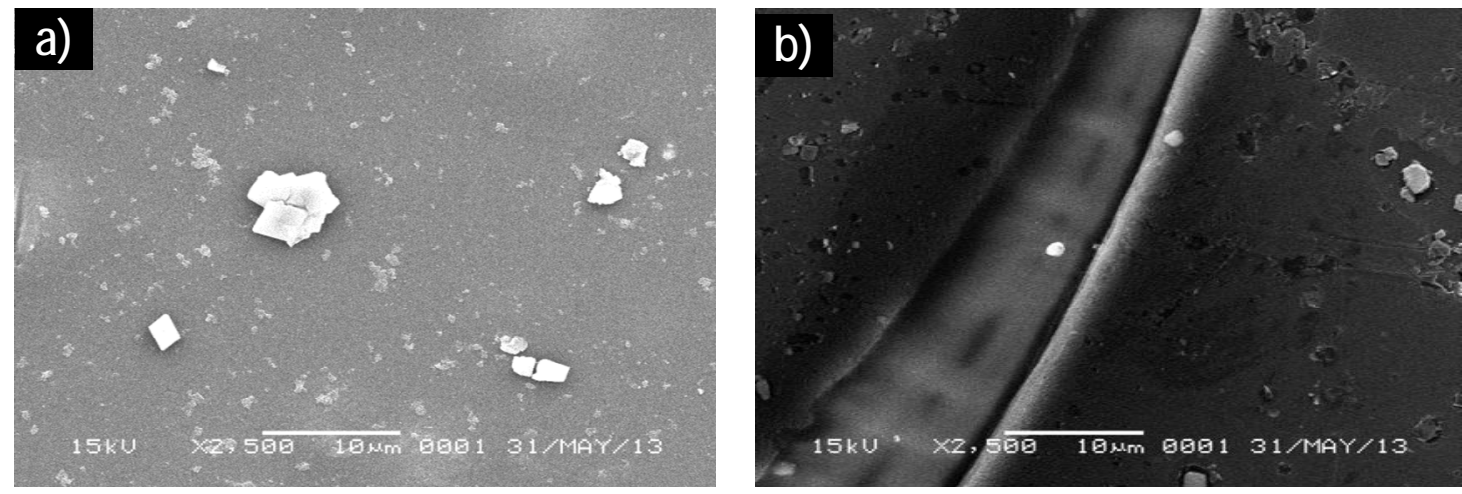

Fig. 5. SEM images of chitosan membrane after crosslinking process: surface (a) and the transverse cross-section (b)

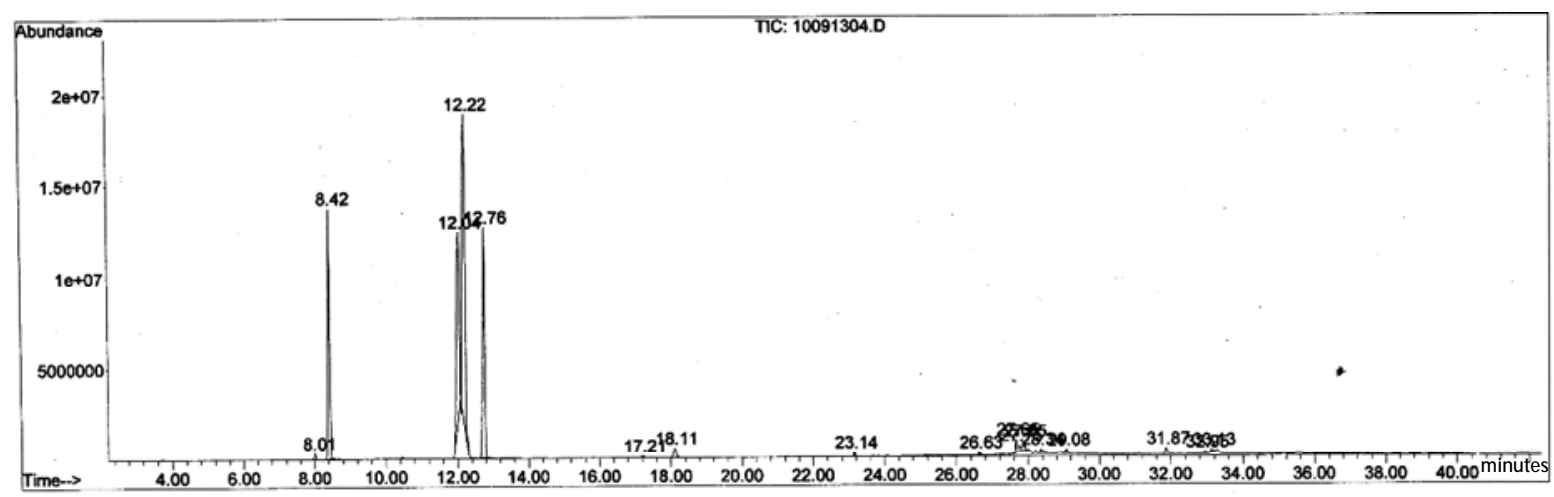

Fig. 6. GC-MS chromatogram of biodiesel from CI oil

Further morphology analysis of the membrane was observed by SEM to get images of membrane crosssection, pores size and distribution. The images of chitosan membrane cross-section and pores distribution with and without crosslinking agents are shown in Figs. 4 and 5. The images show that the membrane surfaces have plenty and uniform pores distribution with average pore size below $10 \mathrm{~nm}$, hence the membranes are suitable for oil purification.

From the biodiesel analyses, moisture content of CI oil and FFA levels were 0.75 and $13.89 \%$, respectively. Because of having high FFA value $(>2.5 \%)$, the synthesis of biodiesel in this study uses two stages process to prevent saponification, namely the stage of esterification and transesterification. Esterification process was performed to reduce the FFA levels (at $\pm 1 \%$ ). This process must be undertaken to prevent the saponification reaction between free fatty acids with alkaline catalyst in the transesterification process. It is noteworthy, that during biodiesel synthesis, soap can lead to the formation of an emulsion that can complicate the purification process. Biodiesel produced was subsequently analyzed by GC-MS to determine the type and content of its compounds (Fig. 6).

Chromatographic results show that biodiesel obtained from CI oil contains four major compounds. The compounds performing extensive areas at 18.367, 20.298, 
35.432 and $20.036 \%$ correspond to methyl palmitate, methyl linoleic, methyl oleate and methyl stearate, respectively. Nevertheless, there is glycerol which is also produced as the by-product and is placed separately from biodiesel; hence the purification process still needs to be done.

During purification process, the mix of biodiesel products was firstly added to water, which increases separation of glycerol from oil phase. This method is very effective for lowering the glycerol content in biodiesel. Based on the analysis results, the amount of glycerol in biodiesel before separation process does not meet ASTM D6751 and RSNI EB 020551 standards (around $0.3014 \pm 0.05 \%)$. The standards define maximum glycerol value in biodiesel being $0.24 \%$ [21]. After proceeding the purification process with glutaraldehyde-crosslinked chitosan membrane for $1 \mathrm{~h}$, the glycerol content in biodiesel is reduced to $0.1429 \pm 0.09 \%$ and meets ASTM D6771 standard. In the process of purifying biodiesel, only glycerol would pass through the pores of the membrane due to the size of the glycerol molecules, which are smaller than molecules of biodiesel components. The viscosity of biodiesel at $313 \mathrm{~K}$ is $4.8 \mathrm{CST}$ with flash point of $439 \mathrm{~K}$ and cloud point of $279 \mathrm{~K}$. These values meet the Indonesian standards, which state that minimum flash point of biodiesel is $373 \mathrm{~K}$ and the maximum cloud point is $291 \mathrm{~K}$. The obtained data ensure that chitosan membrane may be useful for enhancing biodiesel quality to meet the standards ASTM D6751 and RSNI EB 020551.

\section{Conclusions}

Glutaraldehyde-crosslinked chitosan membrane was successfully synthesized from shrimp shell with maximum performance at $3.1 \%$ chitosan concentration and glutaraldehyde concentration of $0.05 \%$. This membrane has been successfully applied for the biodiesel purification and can reduce the glycerol content in biodiesel to $0.1429 \%$. The performance of the membranes to separate glycerol from biodiesel shows rejection percentage $(R)$ of $52.58 \%$ and Flux of $45.09 \mathrm{~W} / \mathrm{m}^{2}$. Characteristics of biodiesel produced from CI seed oil purified with glutaraldehyde-crosslinked chitosan membrane contains alkyl ester $(94.133 \%)$ composed of methyl palmitate (18.367\%), methyl linoleate $(20.298 \%)$, methyl oleate $(35.432 \%)$ and methyl stearate $(20.036 \%)$. Resulting biodiesel has glycerol content about $0.1429 \%$, viscosity value about 4.8 CST, flash point of $439 \mathrm{~K}$ and cloud point of $279 \mathrm{~K}$.

\section{Acknowledgements}

Authors thank to Ministry of Science, Technology, and Higher Education, Indonesia also Airlangga University for Mandat research program.

\section{References}

[1] Singh R. Hybrid Membrane Systems for Water Purification: Technology, Systems Design and Operations. Elsevier, 2006.

[2] Wafiroh S. and Humairo A: Proceed. $3^{\text {rd }}$ Int. Conf. and Workshops on Basic and Applied Universitas Airlangga, Indonesia, Surabaya 2011, 324.

[3] Van Reis R. and Zydney A.: Curr. Opin. Biotechnol. 2001, 12(2), 208.

[4] Mittelbach M.: Bioresour. Technol., 1996, 56, 7.

[5] Neher A., Haas T., Arntz D. et al.: US Pat. 5387720A, Publ. Feb. 7, 1995.

[6] Wafiroh S. and Febriana H.: Proceed. $2^{\text {nd }}$ Int. Conf. on Chemical Sciences, Indonesia, Yogyakarta 2010, 145.

[7] Pabby A., Rizvi S. and Requena A.: Handbook of Membrane Separations: Chemical, Pharmaceutical, Food, and Biotechnological Applications. CRC Press Taylor \& Francis Group: Boca raton 2015.

[8] Dube M., Tremblay A. and Liu J.: Bioresour. Technol., 2007, 98, 639.

[9] Wang Y., Wang X., Liu Y. et al.: Fuel Process. Technol., 2009, 90, 422 .

[10] Chaudhary J., Vadodariya N., Nataraj S. and Meena R.: ACS Appl. Mater. Interfaces, 2015, 7, 24957.

[11] Croisier F. and Jerome C.: Eur. Polym. J., 2013, 49, 780.

[12] Dotto G., Moura J., Cadaval T. and Pinto L.: Chem. Eng. J., 2013, 214, 8.

[13] Estevinho B., Rocha F., Santos L. and Alves A.: Trends Food Sci. Technol., 2013, 31, 138.

[14] Ikinci G., Senel S., Akincibay H. et al.: Int. J. Pharm., 2002, 235, 121 .

[15] Saleh J., Tremblay A. and Dube M.: Fuel, 2010, 89, 2260.

[16] Berchmans H. and Hirata S.: Bioresour. Technol., 2008, 99, 1716.

[17] Kim S.-K.: Chitin, Chitosan, Oligosaccharides and Their Derivatives: Biological Activities and Applications. CRC Press Taylor \& Francis Group, Boca raton 2010.

[18] Corazzari I.,; Nistico R., Turci F. et al.: Polym. Degrad. Stab., 2015, 112, 1.

[19] Khor E. and Lim L.: Biomaterials, 2003, 24, 2339.

[20] Mulder J.: Basic Principles of Membrane Technology. Springer Science \& Business Media, London 2012.

[21] American Society for Testing and Materials (ASTM). "ASTM D6751-09, Standard Specification for Biodiesel Fuel Blend Stock (B100) for Middle Distillate Fuels." West Conshohocken, PA: ASTM, 2009.

Received: April 26, 2016 / Revised: August 02, 2016 / Accepted: December 12, 2016

\section{ЗАСТОСУВАННЯ ГЛУТАРАЛЬДЕГШД-ЗШИТИХ ХІТОЗАНОВИХ МЕМБРАН 3 ВІДХОДІВ ПАНЦИРІВ КРЕВЕТОК ДЛЯ ВИРОБНИЦТВА БІОДИЗЕЛЮ 3 КАЛОФІЛЕВОЇ ОЛІЇ}

Анотація. Для поліпшення якості $і$ зниюсення вартості виробництва біодизельного палива проведено його очищення 3 використанням глутаральдегід-зшитих хітозанових мембран. Біодизель одержано перестерифікацією калофілевої олії з використанням кислотного каталізатора. Показано, що кількість гліцерину в біодизельному паливі перед прочесом очищення становить 0,3014 $\pm 0,05 \%$. Після проведення очищення протягом 1 год. вміст глічерину в біодизелі зменшується до 0,1429 $\pm 0,09 \%$. мембрана. 